\title{
Soupis prací Petra Karlíka za léta 2010-2020
}

Níže uvedený soupis obsahuje pouze práce za posledních deset let. Navazuje tím na soupis starších prací, který vyšel jednak v jubilejním sborníku Petra Karlíka v roce 2010, jednak v časopise Linguistica Brunensia v roce 2011:

BIČAN, Aleš (ed.). Karlík a továrna na lingvistiku: Prof. Petru Karlíkovi k šedesátým narozeninám. Brno: Host, 2010.

BLAžEK, Václav. Petr Karlík sexagenarius. In Linguistica Brunensia, roč. 59, č. 1-2. Brno: Masarykova univerzita, 2010, s. 253-262.

Další práce dedikované výročím Petra Karlíka jsou také:

Zıková, Markéta - CAHA, Pavel (guest eds.). Linguistica Brunensia, roč. 64, č. 1. Brno: Masarykova univerzita, 2016.

CAHA, Pavel - Ziková, Markéta (eds.). Petr Karlík 70 Festschrift. 2021. URL: https://lingbuzz. $\mathrm{com} / \mathrm{t} / \mathrm{karlik} /$.

ZıkovÁ, Markéta - CAHA, Pavel - Kosek, Pavel. Petru Karlíkovi k sedmdesátinám. Slovo a slovesnost, roč. 82, č. 1, 2021, s. 90-92.

2010

Old Czech Adjectives with the Meaning of Passive Potentials. In HANSEN, Björn - GrkovićMAJor, Jasmina (eds.). Diachronic Slavonic Syntax. Gradual Changes in Focus. MünchenBerlin-Wien: Wiener Slawistischer Almanach, roč. 74, č. 1, s. 99-108.

2011

(+ ŠTíchA, František) Některé jevy nominalizace. In ŠTíchA, František. Kapitoly z české gramatiky. Vyd. 1. Praha: Academia, s. 923-944.

Vedlejší věty s relativy který a jenž: liší se něčím? In Rusınová, Eva (ed.). Přednášky a besedy z XLIV. běhu LŠSS. Brno: Masarykova univerzita, s. 77-91.

2012

Bemerkungen zur Diachronie der tschechischen -ní-/-tí-Derivate. Anzeiger für Slavische Philologie. Graz: Akademische Druck- und Verlagsanstalt, roč. 39, s. 113-145.

Brzdy pasiva. Opera slavica. Brno: Ústav slavistiky, Filozofická fakulta Masarykovy univerzity, roč. 22, Suppl., s. 57-65.

České syntaktické bádání od Šmilauera po dnešek očima Prahy a Brna. In ČMEJRKovÁ, Světla 
- Hoffmannová, Jana - Klímová, Jana. Čeština v pohledu synchronním a diachronním Stoleté kořeny Ústavu pro jazyk český. Praha: Karolinum, s. 55-60.

(+ PANEvovÁ, Jarmila) Dva pohledy na vývoj českého poválečného syntaktického myšlení. Korpus - gramatika - axiologie. Praha: Ústav pro jazyk český AV ČR, roč. 5, s. 34-53.

Einige linguistische Anmerkungen zur Figura etymologica. Anzeiger für Slavische Philologie. Graz: Akademische Druck- und Verlagsanstalt, roč. 40, s. 39-50.

Jeden typ relativních vět v češtině. In Rusinová, Eva (ed.). Přednášky a besedy z XLV. běhu LŠSS. Vyd. 1. Brno: Masarykova univerzita, s. 88-100.

Př́ruční mluvnice češtiny. KARLík, Petr - Nekula, Marek - Rusínová, Zdenka (eds.). Vyd. 2., opr. Praha: NLN.

$\mathrm{Zu}$ einigen Eigenschaften der tschechischen Personalpronomina. In HANSEn, Björn (ed.). Diachrone Aspekte slavischer Sprachen. München: Verlag Otto Sagner, s. 139-152.

\section{3}

K vztažným větám bez hlavy. In FALTÝNEK, Dan - Gvoždiak, Vít (eds.). Tygramatika. Vyd. 1. Praha: Dokořán, s. 91-106.

Online „New Encyclopedic Dictionary of Czech“. Czech Language News, č. 37, s. 2-5.

Stage level a individual level predikáty. In Rusinová, Eva (ed.). Přednášky a besedy ze XLVI. běhu LŠSS. Brno: Masarykova univerzita, s. 78-85.

Supinum v češtině. In JesenšEk, Marko (ed.). Miklošičeva monografia. Ljutomer: Gimnazija Franca Miklošiča, s. 205-216.

2014

Gramatika a lexikon češtiny. Vyd. 1. Brno: Masarykova univerzita.

2015

Co je to modalita? In Rusinová, Eva (ed.). Přednášky a besedy ze XLVIII. ročníku LŠSS. Brno: Masarykova univerzita, s. 58-69.

2016

Nový encyklopedický slovník češtiny. Karlík, Petr - Nekula, Marek - PlesKalová, Jana (eds.). Praha: NLN. Online na adrese: https://www.czechency.org/index.html

$\mathrm{K}$ jednomu typu otázek v češtině. In Rusinová, Eva (ed.). Přednášky a besedy ze XLIX. ročníku Letní školy slovanských (bohemistických) studií. Brno: Masarykova unvierzita, s. 79-89.

(+ Blaszcyk, Izabela) Zur Analyse der Wh-Extraktion aus untergeordneten Sätzen (mit besonderer Berücksichtigung des Tschechischen und Polnischen). Anzeiger für Slavische Philologie. Graz: Akademische Druck- und Verlagsanstalt, roč. 43, č. 1, s. 27-42.

2017

Čeština jakožto jazyk s nulovým subjektem. In Rusınová, Eva (ed.). Přednášky a besedy z L. (jubilejního) ročníku Letní školy slovanských (bohemistických) studií. Brno: Filozofická fakulta Masarykovy univerzity, s. 114-127.

Zu einer Strategie in der Syntax (am Beispiel von Relativsätzen ohne Korrelat). Anzeiger für Slavische Philologie. Graz: Akademische Druck- und Verlagsanstalt, roč. 44, s. 15-24. 


\section{8}

Deverbální substantiva v češtině ( $\mathrm{z}$ hlediska češtiny jako cizího jazyka). In Rusınová, Eva (ed.). Přednášky a besedy z LI. ročníku Letní školy slovanských bohemistických studiu. Brno: Masarykova univerzita, s. 121-134.

Ke statusu subjektových vět. In MALčík, Petr (ed.). Vesper Slavicus. Sborník k nedožitým devadesátinám prof. Radoslava Večerky. Praha: NLN, s. 113-130.

\section{9}

Externí argument v pasivní struktuře v češtině a jinde. In Rusinová, Eva (ed.). Letní škola slovanských (bohemistických) studií. Brno: Masarykova univerzita, s. 126-142.

K foneticky nevyjádřenému subjektu v češtině. In HoRÁk, Aleš - RYchLÝ, Pavel - RAMBouSEK, Adam (eds.). Slavonic Natural Language Processing in the 21th Century. Brno: Tribun EU, s. 122-132.

Škála nominalizací. In MALČín, Petr - KARLÍk, Petr (eds.). Svět podle Grepla. Prof. Miroslavu Greplovi k devadesátým narozeninám. Vyd. 1. Brno: Host, s. 91-110.

2020

By-fráze v českém participiálním pasivu (cesta k analýze pasiva). Naše řeč. AV ČR, Ústav pro jazyk český, roč. 103, č. 1-2, s. 97-112.

Der Tod des Supinums (Ein Blick in die Geschichte der tschechischen Grammatik). In Etymologus. Festschrift for Václav Blažek. Hamburg: Baar-Verlag, s. 233-243.

(+ Kosta, Petr) Die Nominalisierung von Nebensätzen im Tschechischen. Zeitschrift für Slawistik. Berlin: Akademie-Verlag, roč. 65, č. 4, s. 479-497.

Přechodníky v kontextu nominalizací. In BíLKovÁ, Jana - KoLÁŘovÁ, Ivana - VoNDRÁčEK, Miloslav (eds.). Lingvistika. Korpus. Empirie. Praha: Ústav pro jazyk český AV ČR, s. 17-27.

Pozn.: Symbol „+“ znamená „spoluautor“.

\section{Poděkování}

Ráda bych poděkovala PhDr. Heleně Karlíkové, CSc., za kontrolu a doplnění výše uvedených dat.

\section{Lucie Janků}

Department of Czech Language

Faculty of Arts, Masaryk University

Arna Nováka 1, 602 oo Brno

Czech Republic

lucieljanku@gmail.com 
